\title{
Passive and Active Restoration Strategies to Activate Soil Biogeochemical Nutrient Cycles in a Degraded Tropical Dry Land
}

\author{
Manuel F. Restrepo, Claudia P. Florez, Nelson W. Osorio, and Juan D. León \\ Universidad Nacional de Colombia, Calle 59A No. 63-20, Oficina 14-225 050034, Medellín, Colombia \\ Correspondence should be addressed to Juan D. León; jdleon@unal.edu.co
}

Received 30 April 2013; Accepted 6 June 2013

Academic Editors: J. A. Entry and D. Lin

Copyright (C) 2013 Manuel F. Restrepo et al. This is an open access article distributed under the Creative Commons Attribution License, which permits unrestricted use, distribution, and reproduction in any medium, provided the original work is properly cited.

\begin{abstract}
The potential use of two restoration strategies to activate biogeochemical nutrient cycles in degraded soils in Colombia was studied. The active model was represented by forest plantations of neem (Azadirachta indica) (FPN), while the passive model by successional patches of native plant species was dominated by mosquero (Croton leptostachyus) (SPM). In the field plots fine-litter traps and litterbags were established; samples of standing litter and surface soil samples $(0-10 \mathrm{~cm})$ were collected for chemical analyses during a year. The results indicated that the annual contributions of fine litterfall in FPN and SPM were 557.5 and $902.2 \mathrm{~kg} \mathrm{ha}^{-1}$, respectively. The annual constant of decomposition of fine litter $(k)$ was 1.58 for neem and 3.40 for mosquero. Consequently, the annual real returns of organic material and carbon into the soil from the leaf litterfall decomposition were 146 and $36 \mathrm{~kg} \mathrm{ha}^{-1} \mathrm{yr}^{-1}$ for FPN and 462 and $111 \mathrm{~kg} \mathrm{ha}^{-1} \mathrm{yr}^{-1}$ for SPM, respectively. Although both strategies showed potential to activate soil biogeochemical cycles with respect to control sites (without vegetation), the superiority of the passive strategy to supply fine litter and improve soil properties was reflected in higher values of soil organic matter content and cation exchange capacity.
\end{abstract}

\section{Introduction}

Land degradation in arid and semiarid lands increases as a result of soil misuse or mismanagement, which, together with climatic variations, may promote desertification and reduces soil productivity $[1,2]$. In Colombia, $78.9 \%$ of dry lands show some degree of desertification, mainly due to soil erosion by overgrazing and soil salinity [3]. Passive and active restoration strategies have been proposed to restore the functioning of ecological processes [4]. Passive restoration strategies imply minimal human intervention and are based on natural succession process, and in this way the restorer has a passive role regarding the process. On the other hand, active restoration strategies include planting trees at high density and their respective management [5]; this strategy implies a more active role of the restorer. Although passive restoration strategies are simple, inexpensive, and based on natural regeneration processes, they are not always successful $[6,7]$. Alternatively, active restoration strategies accelerate the restoration of ecosystem functioning through the activation of soil biogeochemical cycling of nutrients and carbon sequestration [4].

The hypothesis of this study is that the activation of soil biogeochemical nutrient cycles and soil quality improvement of degraded dry land depend on the strategy of restoration (active and passive). Thus, the objective of this study was to evaluate the potential use of both active and passive strategies to restore soil biogeochemical nutrient cycles in fine litterfall and soil quality in tropical degraded dry lands by overgrazing. The active restoration strategy consisted of a plantation of neem (Azadirachta indica) established six years ago for restoration purposes in soils severely eroded. The passive restoration strategy consisted of six-year-old successional patches dominated by native species, where mosquero (Croton leptostachyus) is the most abundant plant species that grow in the same eroded soils. To this purpose, we characterized several processes related to fine litterfall dynamics that control the flow of organic matter and nutrients and evaluated some soil physic-chemical parameters. 
TABLE 1: Mean values of structural parameters of the successional patches of mosquero (SPM) and forest plantations of neem (FPN) studied in Antioquia (Colombia); standard deviation in parentheses.

\begin{tabular}{lcc}
\hline Parameters & FPN & SPM \\
\hline DBH $(\mathrm{cm})$ & $3.55(0.85)$ & $1.88(0.97)$ \\
$D_{q}(\mathrm{~cm})$ & $3.89(0.92)$ & $2.91(0.83)$ \\
$H(\mathrm{~m})$ & $3.81(0.46)$ & $1.84(0.53)$ \\
$G\left(\mathrm{~m}^{2} \mathrm{ha}^{-1}\right)$ & $1.36(0.76)$ & $0.76(0.24)$ \\
\hline
\end{tabular}

DBH: diameter at breast height $(1.3 \mathrm{~m}), D_{q}$ : mean square diameter, $H$ : height, G: stand basal area.

\section{Material and Methods}

2.1. Research Study Area. This study was conducted in Santa Fe de Antioquia, northeastern Colombia $\left(6^{\circ} 54^{\prime} \mathrm{N}, 75^{\circ} 81^{\prime} \mathrm{W}\right.$, $560 \mathrm{~m}$ of altitude). The annual average temperature, sunlight, precipitation, and evaporation of the region are $26.6^{\circ} \mathrm{C}$, $2172 \mathrm{~h}, 1034 \mathrm{~mm}$, and $1637 \mathrm{~mm}$, respectively, characterized by a pronounced annual water deficit derived from the Precipitation/Evaporation ratio of 0.63 . The landscape consists of hills with a low to medium slope formed from sediments from the Tertiary. The soils are alkaline and classified as Typic Ustorthents (USDA soil taxonomy); the most dominant soil use is grassland and unfortunately it is degraded by overgrazing. The neem plantations studied here (active strategy) were established in 2004 on hillsides severely eroded by overgrazing; since then, forestry management practices have not been carried out. In the middle of these plantations have grown natural successional patches (passive strategy), which are constituted by native plant species heavily dominated by mosquero.

2.2. Field and Laboratory Research Methods. To evaluate the biogeochemical cycle processes we established 20 circular plots of $250-\mathrm{m}^{2}$ in forest plantations (FPN) and 13 similar plots in successional patches (SPM) (Table 1). In each plot three circular litter traps (fine netting of $0.5-\mathrm{m}^{2}$ ) were placed $1-\mathrm{m}$ above the soil surface. Every 15 days for 1 year, we collected the litter material in each plot; it means 60 samples in FPN and 39 samples in SPM per sampling time.

The litterfall was separated in the following fractions: (a) neem leaves (NL), (b) mosquero leaves (ML), (c) leaves from other species (OL), (d) wood material (WM) from branches of $<2-\mathrm{cm}$ diameter and small bark pieces, (e) reproductive material (RM), and (f) other materials (OM). The divided material was oven dried at $65^{\circ} \mathrm{C}$ and weighed. The samples of NL and ML were then separately combined and homogenized for every two 15-day periods (1 month) and a subsample was taken for chemical analysis. At the end of the year, samples from the accumulated litterfall layer or standing litter layer on the soil of the plantations and successional patches (a $50 \times 50 \mathrm{~cm}$ sample per plot) were collected. Each sample was separated in the same fractions than fine litterfall. Each fraction was dried at $65^{\circ} \mathrm{C}$ until reaching constant mass $(72 \mathrm{~h})$ and weighed. A composite and homogenized sample from each fraction was prepared for chemical analysis.
The decomposition of neem and mosquero leaf litter was studied by installing 18 litter-bags $(20 \times 20 \mathrm{~cm}, 2 \mathrm{~mm}$ pores $)$ with $3 \mathrm{~g}$ of senescent dry leaves per plant species. Three litter-bags were randomly retrieved monthly. The residual leaf material was air-dried, cleaned with a brush to remove soil particles, dried at $65^{\circ} \mathrm{C}$ and weighed and named "residual dry matter" (RDM). The samples from the three collected litter-bags in plantations and successional patches were then separately combined and homogenized for chemical analysis. Additionally, in each plot of successional patches and forest plantations, surface soil samples $(0-10 \mathrm{~cm}$ depth) were collected. Soil samples were also collected from 13 control sites where there was not vegetation; soil samples were transported to laboratory for physical and chemical analyses.

2.3. Physical and Chemical Analyses. Leaf nutrient contents were analyzed by different methods: carbon (C) by the Walkley and Black method, nitrogen $(\mathrm{N})$ by the Kjeldahl method, phosphorus (P) by the molybdate-blue method; calcium $(\mathrm{Ca})$, magnesium $(\mathrm{Mg})$, and potassium $(\mathrm{K})$ by atomic absorption spectroscopy.

In soil samples the methods used were $\mathrm{pH}(1: 2$, water), total N (Nt) (Kjeldahl method), available P (Bray-Kurtz's method), exchangeable $\mathrm{Ca}, \mathrm{Mg}$, and $\mathrm{K}$ (1 M ammonium acetate; atomic absorption spectroscopy). We also determined soil bulk density (BD) and aggregate stability (AS) (Yoder method). Details about soil and plant analysis methods are available in Westerman [8].

2.4. Statistical Analysis and Calculations. The rate of potential nutrient return (PNR) by the leaf litterfall was calculated as the product of the nutrient concentration and the dry mass of the leaf litterfall. The retention of nutrients in the standing litter (RNSL) was obtained by multiplying the dry weight of the leaves present in the standing litter and their respective concentration. We calculated nutrient release from the decomposition coefficient $k_{j}$ as proposed by Jenny et al. [9]: $\left[k_{j}=\mathrm{PNR} /(\mathrm{PNR}+\mathrm{RNS})\right]$. The mean residence time (MRT) of litterfall and nutrients was calculated as the inverse of $k_{j}$. The real rate of nutrient return (RNR) from the leaf litterfall was calculated as the product of PNR and the corresponding $k_{j}$ coefficient [10].

The weight loss in the litter-bags was expressed by a simple exponential model [11]:

$$
\frac{X_{t}}{X_{0}}=e^{-k t},
$$

where $X_{t}$ is the weight of the remaining material at moment $t, X_{0}$ is the weight of the initial dry material, $e$ is the basis of natural logarithm, and $k$ is the decomposition rate. The time required to obtain losses of $50 \%$ and $99 \%$ of the dry material was calculated as $t_{50}=-0.693 / k$ and $t_{99}=-4.605 / k$, respectively.

Regression models were fitted using nonlinear regression for the weight loss of leaf material deposited in the litter-bags. Linear coefficient of determination $\left(R^{2}\right)$, the Durbin-Watson (D-W) coefficient, and the sum of the squares of the error were employed to select the models. Correlation analyses 
TABLE 2: Mean values of fractions for fine litter production (FLP) $\left(\mathrm{kg} \mathrm{ha}^{-1} \mathrm{yr}^{-1}\right)$ and standing litter (SL) ( $\left.\mathrm{kg} \mathrm{ha}^{-1}\right)$ in successional patches (SP) and forest plantations (FP). Standard deviation is in parentheses. ML and NL: leaf litter of mosquero and neem in their respective ecosystem; OL: other leaves; RM: reproductive material; WM: woody material; OR: other rests unidentified.

\begin{tabular}{|c|c|c|c|c|c|c|c|c|}
\hline \multirow{3}{*}{ Fraction } & \multicolumn{5}{|c|}{ FLP } & \multirow{2}{*}{\multicolumn{3}{|c|}{$\begin{array}{c}\mathrm{SL} \\
\left(\mathrm{kg} \mathrm{ha}^{-1} \mathrm{yr}^{-1}\right)\end{array}$}} \\
\hline & \multicolumn{3}{|c|}{ (kg ha ${ }^{-1}$ per two weeks) } & \multicolumn{2}{|c|}{$\left(\mathrm{kg} \mathrm{ha}^{-1} \mathrm{yr}^{-1}\right)$} & & & \\
\hline & SPM & FPN & $t$ value & SPM & FPN & SPM & FPN & $t$ value \\
\hline $\mathrm{ML}, \mathrm{NL}$ & $15.4(10.6)$ & $8.0(6.2)$ & $2.85^{* *}$ & 477.9 & 184.8 & 238.9 & 73.1 & $4.87^{* * *}$ \\
\hline $\mathrm{OL}$ & $3.1(3.1)$ & $7.3(3.3)$ & $4.43^{* * *}$ & 116.9 & 176.9 & 46.7 & 181.3 & 2.35 \\
\hline RM & $8.7(6.9)$ & $5.8(6.0)$ & 1.07 & 227.1 & 135.8 & ND & ND & ND \\
\hline WM & $1.7(1.6)$ & $1.9(0.9)$ & 0.74 & 52.7 & 48.1 & 64.3 & 111.8 & 0.17 \\
\hline OR & $0.5(1.0)$ & $0.5(0.5)$ & 0.28 & 27.6 & 11.9 & 19.11 & 84.9 & 0.0002 \\
\hline Total & $29.3(18.3)$ & $23.4(11.5)$ & 1.09 & 902.2 & 557.5 & 369.0 & 451.1 & 1.08 \\
\hline
\end{tabular}

**, *** Denote significant differences between means at $P$ values $\leq 0.01$ and $\leq 0.001$, respectively $(t$-test). ND: not determined.

TABLE 3: Fitted models for residual dry matter (RDM) as a function of time for neem and mosquero leaf litter.

\begin{tabular}{|c|c|c|c|c|c|c|c|}
\hline Plant species & Model & $t_{0.5}$ & $t_{0.99}$ & $k$ & $R^{2}$ & SSR & $\mathrm{D}-\mathrm{W}$ \\
\hline Mosquero (C. leptostachyus) & $\mathrm{RDM}=1.29 * e^{(-0.00919934 * t)}$ & 0.21 & 1.37 & 3.36 & 0.97 & 0.06 & 1.31 \\
\hline $\operatorname{Neem}($ A. indica $)$ & $\mathrm{RDM}=3 * e^{(-0.00433362 * t)}$ & 0.44 & 2.91 & 1.58 & 0.84 & 0.01 & 0.18 \\
\hline
\end{tabular}

$t_{0.5}$ : decomposition time for half of the leaf litter, $t_{0.99}$ : decomposition time for $99 \%$ of the leaf litter, $k$ : yearly decomposition rate, $R^{2}:$ coefficient of determination, SSR: sum of squared error, D-W: Durbin-Watson statistics.

(r-Pearson, $P \leq 0.05)$ were also used to determine associations between weight loss rates and precipitation. Because litter data were normally distributed, a $t$-test was used to determine the differences in fine litter production, standing litter, and potential nutrient return between SPM and FPN. To compare soil parameters between control sites and both restoration strategies the Mann-Whitney (Wilcoxon) comparison test $(P \leq 0.05)$ was employed since these data were not normally distributed. The analyses were performed with Statgraphics Centurion XV (StatPoint Technologies, Inc.).

\section{Results and Discussion}

3.1. Fine Litter Production, Accumulation, and Decomposition. The results of this study clearly showed that there were significant differences between the active and passive strategies characterized here to activate soil biogeochemical nutrient cycles in tropical dry lands. The annual production of leaf litter and total fine litter per unit area was 2.6-times and 1.6-times higher in SPM than in FPN (Table 2). The higher fine litter production found in SPM represents a greater potential return of organic matter to these degraded soils than that of FPN. The clear dominance of the leaf fraction in fine litter found in both types of ecosystems has been reported in other studies [12]. This also determines a potential source of nutrients for soil recovery because the higher decomposition rate of this fraction represents a faster nutrient return path [13]. By comparing the fine litterfall values with other studies, the FPN were lower than those of tropical lowland forest plantations with $c a$. of $5-10 \mathrm{Mg} \mathrm{ha}^{-1} \mathrm{y}^{-1}$ [1416]. The fine litterfall values found in the SPM coincided with other tropical dry successional forests ( 0.3 to $4.2 \mathrm{Mg} \mathrm{ha}^{-1} \mathrm{y}^{-1}$ ) as reported by Descheemaeker et al. [17].

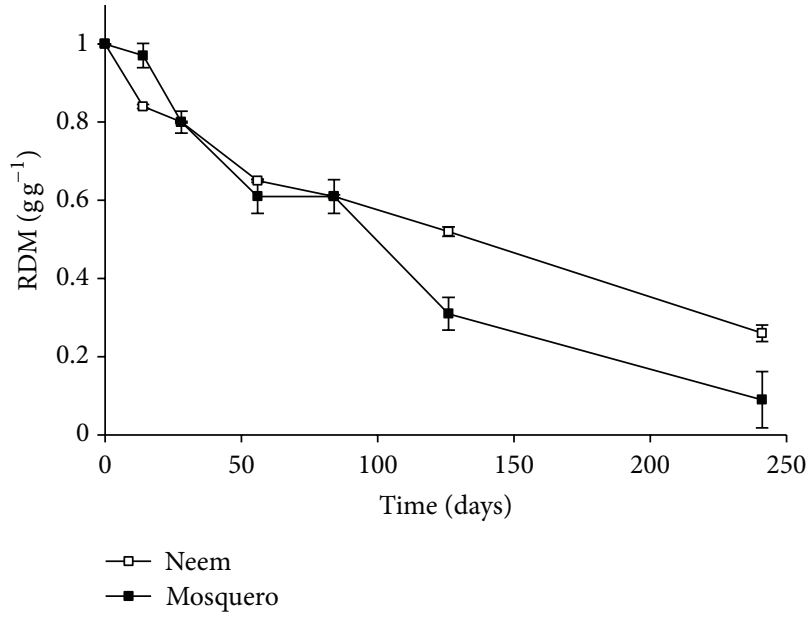

FIGURE 1: Residual dry matter (RDM) from leaf litter of neem $(A$. indica) and mosquero (C. leptostachyus). Each point represents the average of three litter-bags. The bars indicate the standard deviation.

In the results we saw a contradiction about which type of leaf litter decays faster. The constant of decomposition $(k)$ showed that mosquero leaves are decomposed faster than neem leaves. In fact, it was noteworthy that the $k$ constant of mosquero (3.4) was more than twice that of neem (1.6), and the models predicted that the estimated time for $99 \%$ decomposition of leaf litter is $1.4 \mathrm{yr}$ and $2.9 \mathrm{yr}$, respectively (Table 3 ). Furthermore, at the end of the litterbags experiment, the RDM was $9 \%$ and $26 \%$ for mosquero and neem, respectively (Figure 1). However, if we consider the changes in the participation of neem and mosquero leaves collected in the litterfall traps ( 32 and $53 \%$, resp.) with respect 
TABLE 4: Mean monthly values $( \pm \mathrm{SD})$ for leaf litter nutrient concentration (LLC, \%) and potential nutrient return $\left(\mathrm{PNR}, \mathrm{kg} \mathrm{ha}^{-1}\right)$ via leaf litter in successional patches of mosquero (SPM) and forest plantations of neem (FPN) studied. Coefficient of variation (\%) in parentheses.

\begin{tabular}{|c|c|c|c|c|c|c|c|}
\hline \multirow{2}{*}{ Nutrient $^{\mathrm{a}}$} & \multicolumn{2}{|c|}{ LLC (\%) } & \multicolumn{2}{|c|}{$\operatorname{PNR}\left(\mathrm{kg} \mathrm{ha}^{-1}\right)$} & \multirow{2}{*}{$t$ value } & \multirow{2}{*}{$e$-value } & \multirow{2}{*}{$n$} \\
\hline & SPM & FPN & SPM & FPN & & & \\
\hline $\mathrm{N}$ & $\begin{array}{c}1.08 \pm 0.13 \\
(11.9)\end{array}$ & $\begin{array}{c}1.29 \pm 0.31 \\
(24.2)\end{array}$ & $\begin{array}{c}0.44 \pm 0.35 \\
(78.9)\end{array}$ & $\begin{array}{c}0.20 \pm 0.18 \\
(114.4)\end{array}$ & 2.105 & $0.047^{*}$ & 12 \\
\hline $\mathrm{P}$ & $\begin{array}{c}0.05 \pm 0.01 \\
\quad(15.6)\end{array}$ & $\begin{array}{c}0.03 \pm 0.01 \\
\quad(19.0)\end{array}$ & $\begin{array}{c}0.02 \pm 0.02 \\
\quad(79.2)\end{array}$ & $\begin{array}{c}0.005 \pm 0.004 \\
(86.7)\end{array}$ & 3.052 & $0.006^{* *}$ & 12 \\
\hline $\mathrm{Ca}$ & $\begin{array}{c}1.75 \pm 0.33 \\
(18.9)\end{array}$ & $\begin{array}{c}2.16 \pm 0.65 \\
\quad(30.1)\end{array}$ & $\begin{array}{c}0.76 \pm 0.60 \\
(79.7)\end{array}$ & $\begin{array}{c}0.39 \pm 0.44 \\
(82.0)\end{array}$ & 1.721 & $0.099^{\mathrm{NS}}$ & 12 \\
\hline $\mathrm{Mg}$ & $\begin{array}{c}0.59 \pm 0.08 \\
(13.9)\end{array}$ & $\begin{array}{c}0.46 \pm 0.06 \\
(13.9)\end{array}$ & $\begin{array}{c}0.25 \pm 0.21 \\
(83.4)\end{array}$ & $\begin{array}{l}0.07 \pm 0.06 \\
\quad(64.5)\end{array}$ & 2.829 & $0.010^{* *}$ & 12 \\
\hline K & $\begin{array}{c}0.28 \pm 0.13 \\
(44.9)\end{array}$ & $\begin{array}{c}0.29 \pm 0.14 \\
(49.3)\end{array}$ & $\begin{array}{c}0.09 \pm 0.08 \\
(80.2)\end{array}$ & $\begin{array}{c}0.04 \pm 0.03 \\
(89.0)\end{array}$ & 2.226 & $0.036^{*}$ & 12 \\
\hline
\end{tabular}

${ }^{a}$ Analytical methods in Westerman [8]. ${ }^{*}, * *$ Denote significant differences between means of PNR at $P$ values $\leq 0.05$ and $\leq 0.01$, respectively $(t$-test).

to their participation in the standing litter (SL) (16 and 64\%, Table 2), this suggests that neem leaves decomposed faster. It is necessary to consider that the neem leaves are fragile and can be easily fragmented, and for this reason they can be part of the OR fraction (plant remains unidentified). Thus, the OR fraction (OR/total) was only $2 \%$ in the fine litter (FLP) collected in the traps, while this was $19 \%$ in the standing litter (SL). Consequently, we accepted that the $k$ is a better indicator and mosquero leaves decay faster. In the litter-bags experiment the RDM of mosquero was only $9 \%$ which is lower than that of neem 26\%. Also, in the field the SL of FPN is higher suggesting that the decomposition of neem leaves is slower and for that reason they tend to accumulate on the soil surface. It has been reported that forest plantations with exotic species usually generate significant accumulations of litter on the ground [18-20]. Despite this accumulation, the values found in the SL are relatively low in comparison to those reported by other authors [10, 20, 21]. Perhaps, this is a result of the young age of these forest plantations, lack of canopy closure, and low fine litterfall. The $k$ values of mosquero litter are comparable to those reported in tropical arid ecosystems by several authors $[15,22,23]$.

The high rate of decomposition of organic debris in SPM and therefore their low residence time are aspects of special significance to the reactivation of biogeochemical nutrient cycle in these degraded soils [24]. The inverse relationship between the RDM in the litter-bags and the precipitation in SPM (r-Pearson $=-0.59, P<0.05$ ) indicates the favorable effect of the precipitation as a source of moisture for the decomposer microorganisms; perhaps, this was not observed in the FPN because of the limitations of degrader microbes to decompose nonnative leaf material.

3.2. Return, Accumulation, and Release of Nutrients. In both SPM and FPN, nutrient concentrations in the leaf litter (LLC) followed the sequence $\mathrm{Ca}>\mathrm{N}>\mathrm{Mg}>\mathrm{K}>\mathrm{P}$ (Table 4), with the highest temporal variability for $K$. The high concentrations of $\mathrm{Ca}$ and $\mathrm{Mg}$ in the leaf litter found in this study (1.75 and 2.16\%) differ from those found in other tropical dry lowland forests [23], likely due to the high soil availability of both nutrients (Table 6). By contrast, the low concentration of $\mathrm{K}$ in the leaf litter $(0.28-0.29 \%)$ is near the lowest end of the pantropical interval $(0.27 \pm 0.11 \%)$ [25] despite the availability of this nutrient in the soil. Likely, the low soil $\mathrm{Ca} / \mathrm{Mg}$ ratio $<1$ caused an abnormally high $\mathrm{Mg}$ plant uptake and altered the $\mathrm{K}$ uptake [26]. In both ecosystems, the most restrictive nutrient was $\mathrm{P}$ likely as a result of its extreme scarcity in the soil (Table 6), which was reflected in the high values of the leaf litter N/P ratio (FPN: 43, SPM: 20) [10]. These values of the N/P ratio are much higher than the critical value of 11.9 suggested by [27].

The potential nutrient return (PNR) through leaf litter followed the same sequence of concentrations (Table 4) and was significantly higher in SPM because of the higher leaf litter production than in the FPN. Furthermore, the retention of nutrients in the standing litter (RNSL) was higher in SPM, which represents an important source of energy for the micro- and mesofauna, whose participation is a key functional aspect to reactivate the biogeochemical cycling in these degraded soils [28].

The real nutrient return (RNR) via leaf litter was higher in SPM for all nutrients (Table 5). This situation was primarily determined by the higher production of this fraction (ML), despite the fact that in FPN the $K_{j}$ for some elements (C, P, and $\mathrm{K}$ ) was higher or similar $(\mathrm{N})$ to those obtained in SPM. The low RNR of $\mathrm{P}$ also reflected the restrictive nature of this nutrient for the productivity of both ecosystems [10].

In terms of the return and incorporation of organic matter and $\mathrm{C}$ into the soil by leaf decomposition in the SL, the superiority of SPM was notorious (Table 5). Thus, the real return of $C(M L)$ in SPM was more than twice higher than in the FPN (NL). In fact, the highest rate of leaf litter decomposition of mosquero (higher values $K_{j}$ and $k$ ) coincided with the highest contents of soil organic matter in SPM (Table 6). The times needed to achieve a decomposition degree of $99 \%$ of leaves (1.4 yr for mosquero and $2.9 \mathrm{yr}$ for neem) were close to those obtained from the inverse $K_{j}$ in the leaves of the SL (1.5 and 2.0 years, resp.). 
TABLE 5: Indexes calculated for return, retention, and release of nutrients via leaf litter in successional patches of mosquero (SPM) and forest plantations of neem (FPN) $\left(\mathrm{kg} \mathrm{ha}^{-1} \mathrm{yr}^{-1}\right)$.

\begin{tabular}{|c|c|c|c|c|c|c|c|c|c|c|c|c|}
\hline \multirow{2}{*}{ Indexes } & \multicolumn{6}{|c|}{ SPM } & \multicolumn{6}{|c|}{ FPN } \\
\hline & $\mathrm{C}$ & $\mathrm{P}$ & $\mathrm{Ca}$ & $\mathrm{Mg}$ & $\mathrm{K}$ & $\mathrm{N}$ & $\mathrm{C}$ & $\mathrm{P}$ & $\mathrm{Ca}$ & $\mathrm{Mg}$ & K & $\mathrm{N}$ \\
\hline PNR & 114.4 & 0.22 & 8.4 & 2.8 & 1.3 & 5.2 & 45.9 & 0.06 & 4.6 & 0.9 & 0.5 & 2.4 \\
\hline RNSL & 67.9 & 0.18 & 1.6 & 0.2 & 0.9 & 3.9 & 18.0 & 0.03 & 1.5 & 0.3 & 0.1 & 1.8 \\
\hline$k_{j}$ & 0.6 & 0.55 & 0.8 & 0.9 & 0.6 & 0.57 & 0.7 & 0.68 & 0.7 & 0.7 & 0.9 & 0.6 \\
\hline MRT & 1.6 & 1.81 & 1.2 & 1.1 & 1.6 & 1.76 & 1.4 & 1.47 & 1.3 & 1.3 & 1.1 & 1.8 \\
\hline RNR & 71.8 & 0.12 & 7.04 & 2.6 & 0.8 & 2.94 & 33.0 & 0.04 & 3.5 & 0.6 & 0.5 & 1.4 \\
\hline
\end{tabular}

PNR: potential nutrient return rate $\left(\mathrm{kgha}^{-1} \mathrm{yr}^{-1}\right)$, RNSL: retention of nutrients in the standing litter $\left(\mathrm{kgha}^{-1} \mathrm{yr}^{-1}\right), k_{j}$ : decomposition coefficient $\left[k_{j}=\right.$ $\mathrm{PNR} /(\mathrm{PNR}+\mathrm{RNS})]$, MRT: mean residence time $\left[\mathrm{MRT}=1 / k_{j}\right]$, RNR: real nutrient return rate $\left[\mathrm{RNR}=\mathrm{PNR} * k_{j}\right]$.

TABLE 6: Mean values $( \pm \mathrm{SD})$ for some soil parameters $(0-10 \mathrm{~cm})$ in successional patches of mosquero (SPM), forest plantations of neem (FPN), and control sites without vegetation studied in Santafe de Antioquia (Colombia).

\begin{tabular}{|c|c|c|c|c|c|}
\hline Parameter $^{\mathrm{a}}$ & Control sites & SPM & PCI & FPN & $\mathrm{PCI}$ \\
\hline $\mathrm{pH}$ & $6.3 \pm 0.6$ & $6.3 \pm 0.3$ & 0.99 & $6.4 \pm 0.4$ & 1.01 \\
\hline $\operatorname{SOM}(\%)$ & $2.0 \pm 0.9$ & $4.2 \pm 0.4^{*}$ & 2.19 & $3.4 \pm 1.3^{*}$ & 1.72 \\
\hline $\mathrm{Nt}(\%)$ & $0.21 \pm 0.09$ & $0.25 \pm 0.06$ & 1.19 & $0.27 \pm 0.04^{*}$ & 1.27 \\
\hline $\mathrm{P}\left(\mathrm{mg} \mathrm{kg}^{-1}\right)$ & $3.3 \pm 0.9$ & $1.8 \pm 0.5^{*}$ & 0.53 & $4.3 \pm 1.3^{*}$ & 1.31 \\
\hline $\mathrm{Ca}\left(\mathrm{cmol}_{\mathrm{c}} \mathrm{kg}^{-1}\right)$ & $6.2 \pm 2.5$ & $11.6 \pm 3.8^{*}$ & 1.87 & $7.1 \pm 3.6$ & 1.15 \\
\hline $\mathrm{Mg}\left(\mathrm{cmol}_{\mathrm{c}} \mathrm{kg}^{-1}\right)$ & $6.7 \pm 2.8$ & $14.1 \pm 3.4^{*}$ & 2.11 & $7.3 \pm 2.9$ & 1.10 \\
\hline $\mathrm{K}\left(\mathrm{cmol}_{\mathrm{c}} \mathrm{kg}^{-1}\right)$ & $0.23 \pm 0.05$ & $0.25 \pm 0.07$ & 1.14 & $0.36 \pm 0.14^{*}$ & 1.61 \\
\hline $\operatorname{ECEC~}\left(\mathrm{cmol}_{\mathrm{c}} \mathrm{kg}^{-1}\right)$ & $13.0 \pm 4.6$ & $25.9 \pm 6.5^{*}$ & 1.98 & $14.8 \pm 6.0$ & 1.14 \\
\hline $\mathrm{BD}\left(\mathrm{Mg} \mathrm{m}^{-3}\right)$ & $1.35 \pm 0.11$ & $1.25 \pm 0.15^{*}$ & 0.93 & $1.25 \pm 0.09^{*}$ & 0.93 \\
\hline $\mathrm{AE}(\%)$ & $72.8 \pm 10.6$ & $68.5 \pm 12.9$ & 0.94 & $80.1 \pm 9.5$ & 1.10 \\
\hline
\end{tabular}

${ }^{a}$ Analytical methods available in Westerman [8].

PCI: parameter change index (FPN/control or SPM/control), SOM: soil organic matter, ECEC: effective cation exchange capacity, BD: bulk density, AS: aggregate stability. ${ }^{*}$ Indicates significant difference with control sites (Mann-Whitney, $P \leq 0.05$ ).

$\mathrm{N}$ and $\mathrm{P}$ were released more slowly (lower values of $k_{j}$ ) than other nutrients and they are expected to remain longer in the above ground leaf litter, as indicated by MRT values (Table 5). P was released faster in FPN $\left(K_{j}=0.68\right.$, MRT $=1.47$ years), while $\mathrm{N}$ was released at similar rates in both ecosystems $\left(K_{j}=0.57, \mathrm{MRT}=1.76\right.$ years $)$. In both ecosystems, $\mathrm{Ca}$ had the highest release. The time necessary for the effective release of all elements considered in both ecosystems was $1.1-1.81$ years.

3.3. Soil Reclamation. Soils of both SPM and FPN showed changes of some properties with respect to soil of control sites (without vegetation) (Table 6). In SPM significant increases were detected with respect to the control sites on parameters such as soil organic matter the content (SOM), exchangeable $\mathrm{Mg}$ and $\mathrm{Ca}$, and effective cation exchange capacity (ECEC). On the other hand, in FPN were observed significant increases in SOM, total N (Nt), available-P, and exchangeable$\mathrm{K}$ and significant reduction in bulk density (BD).

Despite their short period of time for both strategies, the contributions of fine litter and its decomposition have improved various soil properties of these degraded lands. The sharp increases of SOM observed (compared to control sites) also increased soil moisture retention capacity and soil cation exchange, key aspects in the reclamation of soils of degraded dry land. Although FPN showed a significant increase of P, its very low concentration in the soil determined a severe constraint on ecosystem primary productivity.

\section{Conclusions}

From the perspective of land restoration, both models showed different advantages. The passive model represented by the SPM showed a higher dynamics in the reactivation of soil biogeochemical cycles. It is expected that as the successional process continues the consequently greater complexity of the ecosystem will lead to an effective improvement not only on the soil, but also on ecosystem functions. On the other hand, the active model represented by the FPN showed significant improvements in soil parameters, even though the returns of litter and nutrients were lower. Likely, this situation is the result of differences in litter contributions, whose potential effect on soil rehabilitation has not been fully evaluated. These are issues to consider in selecting a restoration model and the degree and speed expected of the degradation process. Thus, an active model should be considered when the rate of degradation of the area of interest is high, because the planted species can be established quickly and create better conditions for a more diverse biological community as pointed by [5]. When the state and rate of degradation are not severe, the most appropriate model might be the passive restoration, allowing the ecosystem a natural 
recover [29], which had advantages from ecological and economic perspectives.

\section{Acknowledgments}

The authors thank the Direction of Research of the Universidad Nacional de Colombia for financial support of the Project "Restoration of lands in a process of desertification with neem plantations (Azadirachta indica) in Western Antioquia." Juan D. León was supported by Convocatoria Nacional de Investigación y de Creación Artística de la Universidad Nacional de Colombia 2010-2012. They also thank the Biogeochemistry Laboratory of the Universidad Nacional de Colombia at Medellin campus. The authors are grateful to A. N. Marín, L. F. Osorio, J. C. Guingue, G. E. Mazo, and N. Alvarez for their technical collaboration.

\section{References}

[1] Y. Zha and J. Gao, "Characteristics of desertification and its rehabilitation in China," Journal of Arid Environments, vol. 37, no. 3, pp. 419-432, 1997.

[2] J. F. Reynolds and D. M. Stafford Smith, Global Desertification: Do Humans Cause Deserts? Vol. 88, University Press, Berlin, Germany, 2002.

[3] Plan de Acción Nacional de Lucha Contra la Desertificación y la Sequía en Colombia (PAN), Ministerio de Ambiente, Vivienda y Desarrollo Territorial, Bogotá, Colombia, 2004.

[4] D. Celentano, R. A. Zahawi, B. Finegan, R. Ostertag, R. J. Cole, and K. D. Holl, "Litterfall dynamics under different tropical forest restoration strategies in Costa Rica," Biotropica, vol. 43, no. 3, pp. 279-287, 2011.

[5] S. D. Reay and D. A. Norton, "Assessing the success of restoration plantings in a temperate New Zealand forest," Restoration Ecology, vol. 7, no. 3, pp. 298-308, 1999.

[6] K. D. Holl, "Tropical moist forest restoration," in Handbook of Ecological Restoration, M. R. Perrow and A. J. Davy, Eds., pp. 539-558, Cambridge University Press, Cambridge, UK, 2002.

[7] J. Schrautzer, A. Rinker, K. Jensen, F. Muller, P. Schwartze, and C. Dier Ben, "Succession and restoration of drained fens: perspectives from northwestern Europe," in Linking Restoration and Ecological Succession, L. R. Walker, J. Walker, and R. J. Hobbs, Eds., pp. 90-120, Springer, New York, NY, USA, 2007.

[8] R. L. Westerman, Soil Testing and Plant Analysis, Soil Science Society of America, Madison, Wis, USA, 1990.

[9] H. Jenny, S. Gessel, and F. Bingham, "Comparative study of decomposition of organic matter in temperate and tropical regions," Soil Science, vol. 68, pp. 419-432, 1949.

[10] J. D. León, M. I. González, and J. F. Gallardo, "Ciclos biogeoquímicos en bosques naturales y plantaciones de coníferas en ecosistemas de alta montaña de Colombia," Revista Biología Tropical, vol. 59, pp. 1883-1894, 2011.

[11] J. Olson, "Energy storage and balance of producers and decomposer in ecological systems," Ecology, vol. 44, pp. 322-331, 1963.

[12] V. Meentemeyer, E. O. Box, and R. Thompson, "World patterns and amounts of terrestrial plant litter production," Bioscience, vol. 32, pp. 125-128, 1982.

[13] C. Strojan, F. Turner, and R. Castetter, "Litter fall from shrubs in the northern Mojave desert,” Ecology, vol. 60, pp. 891-900, 1979.
[14] J. A. Parrotta, "Productivity, nutrient cycling, and succession in single- and mixed-species plantations of Casuarina equisetifolia, Eucalyptus robusta, and Leucaena leucocephala in Puerto Rico," Forest Ecology and Management, vol. 124, no. 1, pp. 45-77, 1999.

[15] J. Goma-Tchimbakala and F. Bernhard-Reversat, "Comparison of litter dynamics in three plantations of an indigenous timbertree species (Terminalia superba) and a natural tropical forest in Mayombe, Congo," Forest Ecology and Management, vol. 229, no. 1-3, pp. 304-313, 2006.

[16] J. Barlow, T. A. Gardner, L. V. Ferreira, and C. A. Peres, "Litter fall and decomposition in primary, secondary and plantation forests in the Brazilian Amazon," Forest Ecology and Management, vol. 247, no. 1-3, pp. 91-97, 2007.

[17] K. Descheemaeker, B. Muys, J. Nyssen et al., "Litter production and organic matter accumulation in exclosures of the Tigray highlands, Ethiopia," Forest Ecology and Management, vol. 233, no. 1, pp. 21-35, 2006.

[18] J. Sawyer, Plantations in the Tropics: Environmental Concerns, IUCN, Gland, Switzerland, 1993.

[19] A. E. Lugo, “The apparent paradox of reestablishing species richness on degraded lands with tree monocultures," Forest Ecology and Management, vol. 99, no. 1-2, pp. 9-19, 1997.

[20] J. F. Dames, M. C. Scholes, and C. J. Straker, "Litter production and accumulation in Pinus patula plantations of the Mpumalanga Province, South Africa," Plant and Soil, vol. 203, no. 2, pp. 183-190, 1998.

[21] J. F. Dames, M. C. Scholes, and C. J. Straker, "Nutrient cycling in a Pinus patula plantation in the Mpumalanga Province, South Africa," Applied Soil Ecology, vol. 20, no. 3, pp. 211-226, 2002.

[22] S. E. Attignon, D. Weibel, T. Lachat, B. Sinsin, P. Nagel, and R. Peveling, "Leaf litter breakdown in natural and plantation forests of the Lama forest reserve in Benin," Applied Soil Ecology, vol. 27, no. 2, pp. 109-124, 2004.

[23] A. N. Singh, A. S. Raghubanshi, and J. S. Singh, "Comparative performance and restoration potential of two Albizia species planted on mine spoil in a dry tropical region, India," Ecological Engineering, vol. 22, no. 2, pp. 123-140, 2004.

[24] D. L. Moorhead and R. L. Sinsabaugh, "A theoretical model of litter decay and microbial interaction," Ecological Monographs, vol. 76, no. 2, pp. 151-174, 2006.

[25] J. M. Duivenvoorden and J. F. Lips, A Land-Ecological Study of Soils, Vegetation, and Plant Diversity in Colombian Amazonia, Tropenbos, Series 12, The Tropenbos Foundation, Wageningen, The Netherlands, 1995.

[26] H. Marschner, Mineral Nutrition of Higher Plants, Academic Press, London, UK, 1995.

[27] R. Aerts, "Climate, leaf litter chemistry and leaf litter decomposition in terrestrial ecosystems: a triangular relationship," Oikos, vol. 79, no. 3, pp. 439-449, 1997.

[28] F. J. Stevenson, Cycles of Soil, John Wiley \& Sons, New York, NY, USA, 1986

[29] D. Lamb and D. Gilmour, Issues in Forest Conservation. Rehabilitation and Restoration of Degraded Forests, International Union for Conservation of Nature and Natural Resources and World Wide Fund, Cambridge, UK, 2003. 

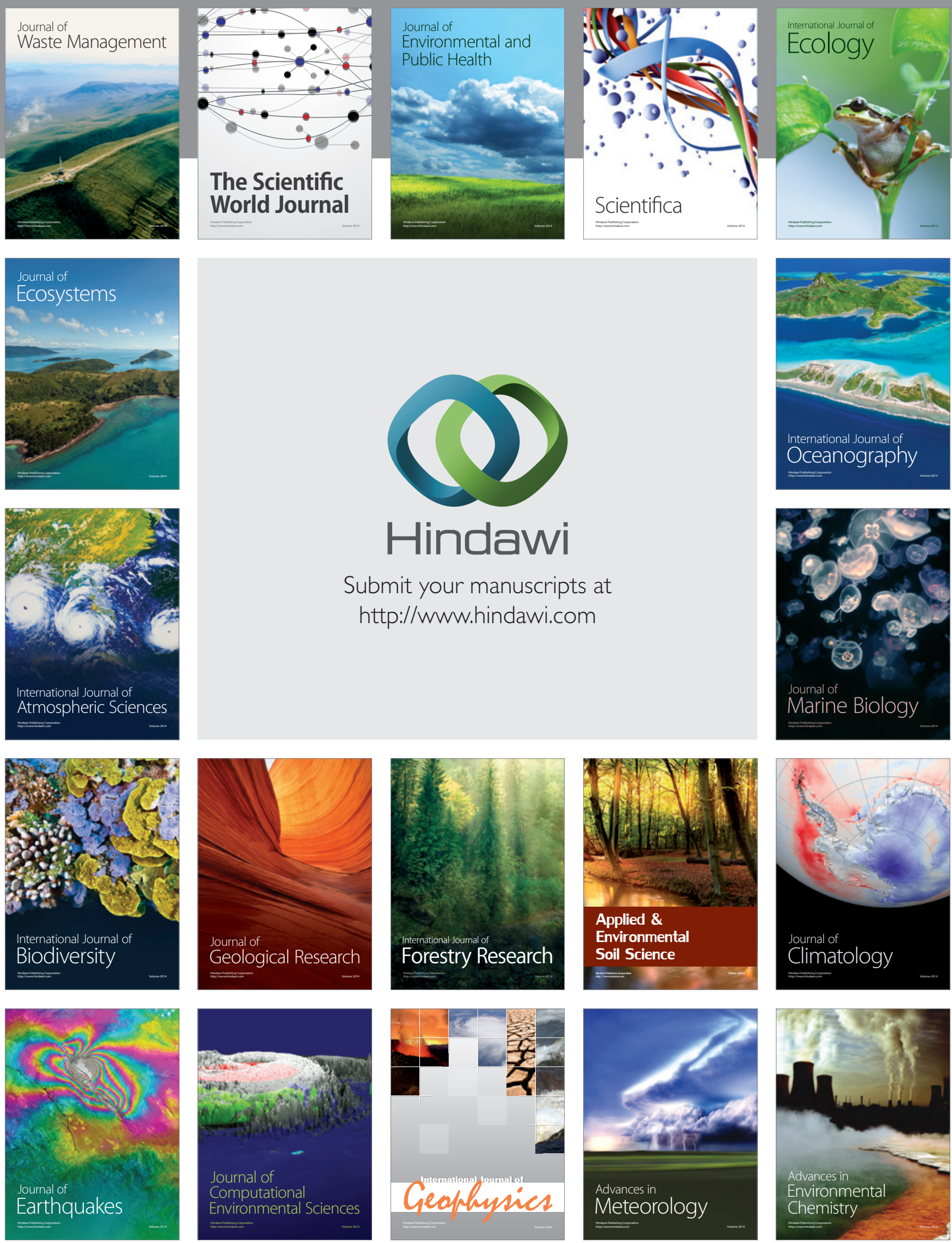